\title{
From preschool educator to preschool English Educator: A study of transformation of classroom practice*
}

De educador de preescolar a educador de inglés en preescolar: un estudio de transformación de prácticas de aula

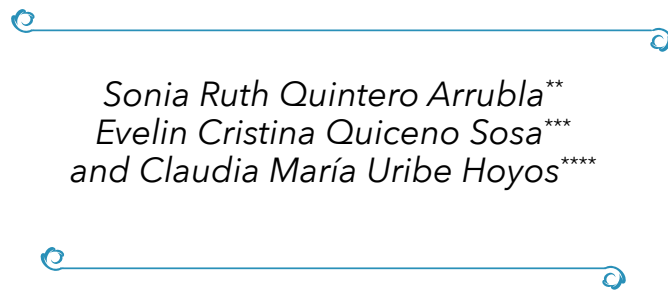

Recibido: 21/08/2020 • Aceptado: 29/01/2021・

* El presente artículo es producto del impacto del programa de desarrollo profesional docente Pre-K English, el cual buscaba determinar los cambios generados por las maestras desde la didáctica en el aula en los establecimientos educativos de las 16 comunas de la ciudad de Medellín y los 5 corregimientos. Programa que nació a partir de la alianza entre la Universidad Católica Luis Amigó, Nutresa y Secretaría de Educación de Medellín de la Gobernación de Antioquia (2013-2017)

** Universidad Católica Luis Amigó, Facultad de Educación y Humanidades, Medellín-Colombia. https://orcid. org/0000-0003-4835-2593

*** Universidad Católica Luis Amigó, Facultad de Educación y Humanidades, Medellín-Colombia. https:// orcid. org/0000-0002-5049-1034

**** Universidad Católica Luis Amigó, Facultad de Educación y Humanidades, Medellín-Colombia. https://orcid. org/0000-0003-3731-4890

\section{Abstract}

This case study aims to analyze how preschool educators can play the role of language educators (Spanish and English) and how their pedagogical and teaching practice is being transformed. This study considers the theoretical framework behind the constructivist paradigm, which states that the context, participants' actions and views, and historical elements all play a part in constructing a theory. That truth is relative depending on one's perspective, while also focusing on establishing a rigorous and thorough process throughout this study, focusing on qualitative research principles (Creswell, 2014). The findings show that preschool educators can significantly improve their communicative competence, particularly in discourse, strategic and socio-cultural competencies. Furthermore, through reflection and self-assessment, preschool educators refine their classroom practices and enhance their conception about teaching English to preschool learners.

Key Words: Communicative competence, English teaching, classroom practices, preschool language educators. 


\section{Resumen}

Este estudio de caso tiene como objetivo analizar cómo los maestros de preescolar pueden desempeñar el papel de educadores de idiomas (español e inglés) y cómo se están transformando sus prácticas pedagógicas. Este estudio considera el marco teórico detrás del paradigma constructivista, que establece que el contexto, las acciones y puntos de vista de los participantes, y los elementos históricos, todos juegan un papel en la construcción de teoría. (Creswell, 2014). Los hallazgos muestran que los educadores de preescolar pueden mejorar significativamente su competencia comunicativa, particularmente en las competencias discursivas, estratégicas y socioculturales. Además, a través de la reflexión y la autoevaluación, los maestros de preescolar refinan sus prácticas en el aula y mejoran su concepción sobre la enseñanza del inglés a los estudiantes de preescolar.

Palabras Clave: Competencia comunicativa, enseñanza del inglés, prácticas de aula, maestros de lenguas en preescolar.

\section{Introduction}

The development of students' communicative competence in English as a foreign language has become an opportunity rather than a requirement. The current globalization process demands that English educators grow a sense of awareness regarding their mother tongue, second language acquisition, and language learning processes during childhood education.

Since English teaching and learning can be complicated, not two educators or learners will go down the same path. Nonetheless, despite all the variables, it has been possible to describe some of the processes that seem familiar to people who struggle to teach and learn the language. Therefore, this paper explores classroom practices' transformations, from Preschool educators to Preschool English educators in this specific case, a Teacher Development Programme for preschool educators developed from 2013 to 2017. Pre-K English Teacher Development Programme was a journey guided by the understanding preschool educators gain from becoming familiar with fundamental elements involved during learning and teaching English. This Pre-K English journey was a fascinating one due to the range of differences and connections encountered along the way. Preschool educators and learners go on a journey sharing dreams, ideas, experiences, growing together while learning the language. 
The Teacher Professional Development Programme: Pre-K English has been created to impact the didactic and pedagogical preschool educators' practices in Medellin public institutions. For this purpose, an academic construction has been created based on a) voluntary participation, b) the possibility of answering to personal and professional needs, and c) the promotion and the encouragement of communities of practice, considering reflections on why and how the teaching and learning English processes in question have been developed (Maturana \& Uribe, 2018). In light of the previous aspects, Pre-K English Programme is designed regarding the concept of Professional Development, leaving aside the idea of training to focus directly on two elements precisely: a) development and improvement of the communicative dimension in English and Spanish, and b) the re-signification of didactic strategies in such a way that the language becomes, for these preschool educators, a possibility of professional and personal strengthening in their classrooms (Universidad Católica Luis Amigó, 2015).

\section{Literature Review}

There are many elements to consider in the process of teaching English in Preschool Education. The nature of this research study is an exploration of the field, bearing in mind a transformation of classroom practices during childhood education. To such a degree, it is indispensable to first refer to the existing body of academic thought concerning language education; therefore, fundamentals bordering on Pedagogical and Didactic Options, Communicative Competence, Teacher Professional Development, and the process of teaching English in Preschool Education are discussed in the present section.

\section{Pedagogical and Didactic Options}

Educators should shape their pedagogical practice according to their observation, reading, and analysis of what takes place in the classroom. Through this process of identifying learning and teaching situations, educators evaluate the outcomes based on their pedagogical practice to see what is best for their learners and identify what practices have worked and what practices require improvement (Kumaravadivelu, 2009).

Didactic options in language education reveal a transparent image about the individualities of any classroom reality; therefore, such an approach characteristic require understanding in practical terms of the context reality combined with language education. Moreover, the acceptance of what happens in 
the preschool classroom related to a language educational reality guides the assumed purposes towards developing communicative competence in Spanish and English.

When pedagogical and didactic options are a matter of concern, it is crucial to consider some macro-strategies and micro-strategies associated with language teaching processes. These predominantly come from theoretical foundations, historical and empirical knowledge, and insights into language teaching education. According to Kumaravadivelu (2002), "a macro-strategy is thus a general plan, a broad guideline based on which teachers will be able to generate their own situation-specific, need-based micro-strategies or classroom techniques" (p.38).

Likewise, pedagogical options and macro-strategies as the next step are reflected as Kumaravadivelu (2002) entitled them as "theory-neutral" or "method-neutral". Theory- neutral means that macro-strategies are not restricted by theoretical principles of second language learning and teaching processes. Alternatively, method-neutral bears in mind that macro-strategies are not influenced by language teaching methods, classroom actions, and theoretical philosophies. Therefore, these considerations lead to some macro-strategies of educators being aware of experimenting and constructing knowledge concerning language education. Preschool classrooms in Colombia are highly diverse, learners come from different scenarios, and not everyone has English as their primary language. Preschool educators should see themselves as language educators to help their learners understand both the concepts worked from the mother tongue and English simultaneously. All educators, no matter the methods and the theoretical philosophies used, need to view themselves as language educators.

The macro-strategy of "Maximizing learning opportunities" Kumaravadivelu (2002), means that teachers should create opportunities to learn in the classroom while balancing their roles as mediators of learning acts and as managers of teaching acts; however, they must also minimize perceptual mismatches by identifying potential variations in interpretation in the context of second language learning. Similarly, to facilitate negotiation as a macro-strategy, teachers must give learning opportunities to interact and negotiate learning topics and not just demand that learners only react and respond to teachers' questions, tasks, and activities. After preschool educators' experience in the programme, it was understandable that it is up to the educator to choose 'tasks' that suit particular learner needs and characteristics. If teachers are jointly responsible for managing learning in the classroom, then it is significant that there is a considerable degree of understanding of the aims and 
activities and the processes and procedures leading classroom language learning and teaching.

As Kumaravadivelu (2002) has stated, when selecting any objective and direction educators should remember that they need a groundwork that allows them to construct knowledge and develop skills and attitudes to obtain autonomy intended for educators to decide and define a personal theory of practice and teaching. This unique theory of teaching should be constructed within the bounds of particularity, practicality, and possibility. Educators must be sensitive to the local, institutional and social context where second language acquisition processes are settled. Practicality refers to a theory of practice where the teacher can practice, evaluate alternatives, explore, identify problems, and choose the proper pedagogical teaching method that suits the daily teaching practice. Lastly, the possibility refers to teachers' sensitivity to develop from taking discussions on issues related to our social, political, cultural, and economic reality.

\section{Communicative Competence}

In education, educators are a guiding light to learners. Preschool educators are determined workers when it comes to trying to get their learners to enjoy English learning. What could easily undermine their joint effort are potential mismatches between their conceptions concerning some fundamentals of the language and the development of their language practices. In this specific matter, the concept of competence has been one of the most discussed terms in applied linguistics. Its relevance to the overview of linguistic discourse is commonly associated with Noam Chomsky (1965) who illustrated a classic distinction between competence (the monolingual speaker listener's knowledge of the language) and performance (the actual use of language in real situations).

Widdowson (1983) has defined competence in terms of the knowledge of linguistic and sociolinguistic conventions, he understood the ability to use knowledge as means of creating meaning in a language. According to him, the ability is not an element of competence, it does not turn into competence, nonetheless remains "an active force for permanent creativity," i.e., a force for the understanding of what Halliday called the "meaning potential" (Widdowson, 1983, p. 27). Having defined communicative competence in this way, Widdowson is the first who reflects on the connection between competence and performance and gives more consideration to real language use.

In an attempt to analyze the concept of communicative competence, Canale and Swain (1980) and Canale (1983) stated communicative competence as 
a synthesis of an entire system of knowledge and skill required for communication. In their communicative competence concept, knowledge refers to the (conscious or unconscious) knowledge of an individual concerning language and aspects of its use. There are three categories of competence: knowledge of essential grammatical codes, knowledge of how to use language in a specific context to accomplish communicative purposes, and how to combine words and communicative functions relating to discourse principles. Likewise, the concept of skill relates to how a learner can use the knowledge in real communication. In the words of Canale (1983), skill involves a further difference between capacity and its manifestation during communication processes. In this sense, in the Pre-K English Teacher Professional Development Program, permanent changes were part of the participating preschool educators, transformations in their behaviors, knowledge, and actions, not only in the development of their English communication skills, but also in values that impact the personal, institutional, and city spheres (Universidad Católica Luis Amigó, 2017).

\section{Teacher Professional Development Programme and classroom practice.}

Numerous approaches have emerged in language teacher education programs in recent years. According to Richards and Farrell (2005), education as a "training" is a methodology that has considered common approaches to teacher education and represents current conventional practices. An additional approach is referred to as "development." According to Richards and Farrell (2005), professional development answers professional growth and how educators appreciate teaching and reflect upon what it means to be a teacher. It refers to teachers' reflection from diverse domains of their pedagogical practices; for instance, how educators apprehend the language and cognitive processes in learning and language acquisition.

The distinction between training and development (with the concept "education" being a general and comprehensive concept) is a valuable way of typifying and describing selections in teacher education. Therefore, it is essential to reflect upon the purposes for which the Pre-K Teachers' Professional Development Programme is envisioned, since this is professional development for educators.

The distinction between these concepts has opened up new possibilities for the contents, methodology, and assessment of teachers' language education. Nevertheless, the only individuals responsible for enacting these changes are the professionals who must ensure harmony with their developmental processes. Consequently, it is fundamental to mention the principal matters, concerning teacher education in national and international settings. A general 
discussion has emerged about teacher education from a university-level in Colombian settings that comprises pre-service teachers. Amaya (1997) reported a crisis concerning pre-service teachers' preparation in Colombian contexts, which was first identified during the 1970s. This situation has persisted in the lack of leadership in the educational processes and lack of innovation regarding pedagogical practices and experiences. In this sense, the Pre-K English Professional Development Programme aimed to prepare preschool educators in English communicative skills to strengthen the language's teaching at this level (Fundación Nutresa, Secretaría de Educación de Medellín, Universidad Católica Luis Amigó, 2014).

As reported by Loaiza-Zuluaga, Sánchez-Girado, Arias-Arteaga, and Palacio-Bernal (2019):

The pedagogical practices stand for the set of actions carried out by the teacher to perform the process of integral formation of his learners. Its proper implementation will allow the learner to develop cognitive, emotional, physical and psychological skills, but, furthermore, it will contribute to their preparation as free, thinking, autonomous, self-realized and ethical human beings. (p. 51)

Therefore, the main objective of educators' preparation in pre-service stages at universities has been the continuous transformation of educational practices, which needs to redefine teaching models, recollect what has been worthy in past processes in education history to construct a different model of preparation bearing in mind the teachers' identity as intellectual, professional of learning and pedagogical knowledge (Amaya, 1997). Based on what has been stated before, for the participants' linguistic and pedagogical development, the Pre-K English Programme developed its two fronts of work with pedagogical and didactic strategies aligned and complementary to each other, which allowed participants to develop the necessary linguistic and pedagogical aspects at the same time to impact the public preschool classrooms of the city of Medellín. (Fundación Nutresa, Secretaría de Educación de Medellín, Universidad Católica Luis Amigó, 2014).

The prerequisite of teachers' humanizing quality has come up against the necessity for teaching qualifications, teaching as a profession has become an enormous concern in our society, "teachers need to maintain a balanced attitude and approach in transforming them to mature individuals" (Kishore, 2000, $\mathrm{p}, 4)$. Nonetheless, educators need to grow or develop themselves as professionals not only in promoting the language but also in strengthening other hu- 
man dimensions; according to Wallace (1991), there is a feeling that language educators must take responsibility for their personal growth and development, bringing into debate the critical language areas that language teachers should accomplish. In Wallace's words, two main dimensions in language teacher preparation should be taken into account. The first is "received knowledge" from theorization and conceptual principles as valuable wand elements of scientific research. The second refers to "experiential knowledge," which is intertwined with educators' practices in their professional development.

\section{English Teaching Processes in Preschool Education}

To teach English to children, it is essential to identify the modifications of learning a second language. Scott and Ytreberg (1990) have divided children into two key groups with different characteristics regarding learning: children from five to seven years old and children from eight to ten years old. Children from five to seven can communicate what they do, they have an intense imagination, use logical reasoning, and comprehend human interaction. Furthermore, children can understand situations first than the language they use. Children recognize better through physical interactions; children love to play and work alone and with others. This characteristic can help English teachers to plan better game activities on behalf of obtaining better learning outcomes. Children from eight to ten years old have a clearer perception of the world, they can influence the decisions educators make, which leads to an increased sense of equality in terms of what occurs inside the classroom. The learning characteristics of children of different ages can help us understand language learning processes and planning of contents, select appropriate utilities, and activities for teaching English at early stages.

When teaching a second language, there has been the hypothesis that acquisition occurs in some order. First, language is presented, and children listen, following the educator's instruction, asking children to produce speech, then written language takes place, and children learn to read, and toward the end, children can develop writing skills (House, 1997). For instance, House (1997) conceived some other reflections when teaching English to children that educators must make allowance for exposure, the practice of language, and the difficulties children have during the writing and reading processes. It is essential to point out that, similarly, that acquiring a language requires time, and by contrast, English classes in local Colombian contexts are very time-limited.

Educators must consider young learners' learning processes on the topic of English teaching at the preschool level. Hence, preschool educators need 
to reflect upon what kinds of methods and approaches to language learning will be used and what kinds of resources are best for children. House (1997) stated that the main objective is to focus on language communication when teaching English to the early stages. Conversely, House (1997) claims that language educators need to provide children with the opportunity to guarantee positive learning since learning in children is not about imposing information; therefore, educators need to bear in mind that every situation can theoretically become a learning situation when teaching children. When teaching English to children, teachers should be aware of some crucial characteristics that children possess.

In this sense, language educators must acknowledge activities that foster oral production and motivate children to interact with others. According to Roberts (2009), a few practices can involve children in early oral language production, including singing, group recitations, peer partner activities, fingerplays, and repeated storybook reading participation. Conversely, Ur (1999) proposed that teaching English activities should be focused on three principal foundations of interests for children: pictures, stories, and games, integrating visual and auditory stimulus and kinesthetic.

These examinations done by the academic community set a call to the preschool educators when planning their classes. They need to consider those pedagogical and didactic elements that are correlated since they are constantly in all stages from the beginning of the process.. Moreover, the relations shaped inside the classroom are not only aimed at the standards and requisites, but most significantly to the fundamental requirements of communication the learners have and are present in the language learning processes; those are the processes that need to be taken care of and lectured in the classes, so existent communication of thoughts, principles, and feelings might take place.

\section{Method}

\section{Context}

This research study arises from the need to understand and explain how preschool educators can play the role of language educators (Spanish and English) and how their pedagogical and teaching practice is being transformed. From an integrated perspective, it is understood that cognitive and emotional processes are involved in the way human beings learn and how contextual factors influence success or failure in different academic scenarios. It has been observed that those educators who initially do not speak English usually deal with more than a few issues that compromise the effective res- 
ponse to academic and real demands. As teachers of a research group called Constructions in Foreign Languages (CILEX), we recognize the importance of developing research projects that help comprehend any educator's reality and transform it from a critical standpoint. For this, leading research on this issue is a chance to deepen into language teaching processes and study it in terms of equity and social responsibility.

The research study reported in this paper was conducted as a case study (Yin, 2003), aiming at deciphering the links built during the process where the preschool educators were immersed, as well as the responses and transitions lived, in order to explain why these events occurred and to have compact elements to elaborate new theoretical perspectives explaining the constructions and transformations. The entire process of data gathering and analysis was developed around a leading question inquiring into the impact that the Teaching Professional Development Program: Pre-K English had caused in the participant preschool pedagogical and didactic practice.

\section{Participants}

The research study was carried out with qualitative methodology, as a case study, and observations, interviews, and focus groups were implemented to obtain the information. The population was 150 preschool educators who graduated from the Pre K-English Teacher Professional Development Program executed in the 2014-2017 period with the following selection criteria: They had participated and completed the Pre K-English Teacher Professional Development Program 2014-2017 at the Catholic University Luis Amigó, being enrolled in the public sector as a childhood educator, and finally having the desire to freely participate in the research study. The methodology comprised three phases, the formulation of the problem, the collection of information, and lastly, the one destined for the analysis and considerations.

As Galeano (2014) stated, one of the most important aspects of qualitative research is its focus on describing and interpreting the qualities and elements that human beings exhibit: aspects that create knowledge and true meaning by enriching the contexts permitting diverse points of view. Qualitative research becomes an exchange of connotations, understandings, and constructions of perspectives that give all the preschool educators a voice. Bearing the previous elements in mind, the researcher becomes a direct participant in the process where there is a genuine need for understanding to show results that are faithful to the whole community's life development, e.g., researchers and other participants. 


\section{Ethical considerations}

Regarding the ethical considerations for this study, it is significant to highlight that permission to conduct the study was granted at the university where it took place; the institution gave the authorization to continue developing the study during the academic period. A set of actions was followed to ensure ethical research practices and participants' identities; the information collected was kept in privacy to ensure preschool educators' confidentiality. They signed up for a consent form where the research process, purpose, procedures, and risks were explained. Furthermore, it was explained to the participants their possibility to withdraw from the research at any moment. As for the analysis process, a document was used to identify each preschool educator's information during the research process. The researchers were the only ones who had access to preschool educators' information.

\section{Data Collection}

For this research study, five different instruments were selected and designed to help in the construction of results which allowed the researchers to make meaningful interpretations of the observed scenarios (Crotty, as cited in Creswell, 2014). While designing and organizing them, the researchers understood the importance of the instruments' assets to interact with the preschool educators to lead to the construction of new questions and aspects to continue the exercise. The following table depicts the instruments used along the process:

Table 1. Research tools used during the process to collect data.

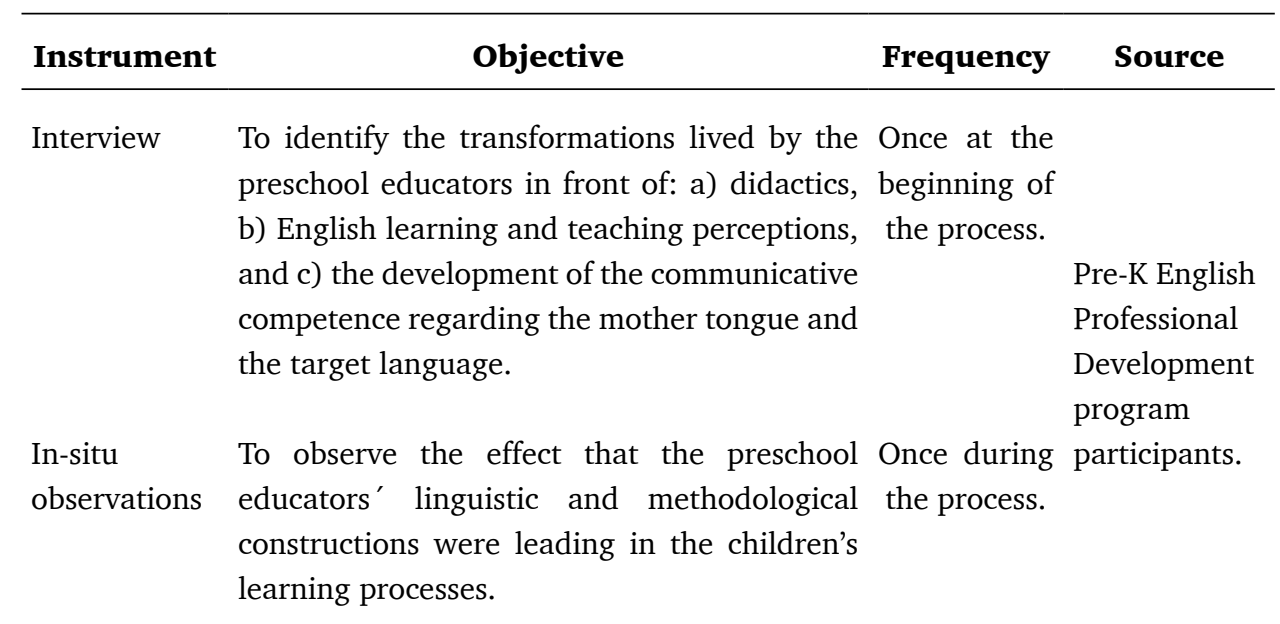




\begin{tabular}{|c|c|c|c|}
\hline Instrument & Objective & Frequency & Source \\
\hline Focus group & $\begin{array}{l}\text { To identify the didactic elements part of the } \\
\text { preschool classroom practices to strengthen } \\
\text { communicative competence in both } \\
\text { languages. }\end{array}$ & $\begin{array}{l}\text { Once at the } \\
\text { end of the } \\
\text { process. }\end{array}$ & \multirow{3}{*}{$\begin{array}{l}\text { Pre-K English } \\
\text { Professional } \\
\text { Development } \\
\text { program } \\
\text { participants. }\end{array}$} \\
\hline $\begin{array}{l}\text { Journal- } \\
\text { Traveling } \\
\text { Notebook. }\end{array}$ & $\begin{array}{l}\text { To identify the transformations lived by the } \\
\text { preschool educators in front of: a) didactics, } \\
\text { b) English learning and teaching perceptions, } \\
\text { and c) the development of the communicative } \\
\text { competence regarding the mother tongue and } \\
\text { the target language. }\end{array}$ & $\begin{array}{l}\text { Once during } \\
\text { the process. }\end{array}$ & \\
\hline $\begin{array}{l}\text { Linguistic } \\
\text { Test- } \\
\text { Comparative } \\
\text { Matrix }\end{array}$ & $\begin{array}{l}\text { To determine discourse and grammatical } \\
\text { improvement in the Preschool educators } \\
\text { participants based on the tests results. }\end{array}$ & $\begin{array}{l}\text { Once at the } \\
\text { end of the } \\
\text { process. }\end{array}$ & \\
\hline
\end{tabular}

Source: prepared by researchers (2018).

For the analysis of data, each instrument was studied. When working with the interviews, the material was graphed to observe the similarities or differences in the answers to define how the three core elements appeared through the participants' responses; the second aspect in the analysis was to contrast the preliminary answers with the ones shown in the set of observations. This data analysis was led bearing in mind two objectives: a) to identify what other questions needed to be addressed while developing the focus group, and $b$ ) to determine "the depths of data", which Burmeister \& Aitken (2012), define as the upward potential of a data set to create varied interpretations. The results of this study are exposed in the following section in this specific order, first at all, from Preschool Educators to English Preschool Educators, subsequently, English Learning Processes Transformations, then, Development and improvement of the communicative competence, which is divided into two subcategories a) discourse and grammatical competence improvement and b) sociocultural competence improvement, in this sense, confidence preschool educators development takes place, and finally, communicative competence in child development. 


\section{Results and Discussion}

\section{From Preschool Educators to English Preschool Educators}

\section{"(...) There is a significant change in the connection during the different pedagogical practices that connect them with the teaching of English \\ (... in the classroom)". \\ (Fragment taken from the Focus Group)}

Educators demonstrated that it was possible to disregard all kinds of stereotypes and misconceptions about their learning English processes to use it naturally, as part of the classroom rituals (Maturana \& Uribe, 2018), and as a common language in the preschool classroom where planning happens based on the context.

English is seen as a whole and as an integral element of preschool education beyond a simple class moment to enlist words or to provide children with instructions to follow, demonstrating that its use and teaching becomes a classroom practice where preschool educators can use all their teaching background and tools, while bearing in mind the cohabitation of both languages. This will lead to a transformative action where both students and teacher develop all their potential regarding the expression of ideas and the construction of new perspectives.

In this sense, preschool educators were asked how they considered the teaching of English to the children in their classes before going through the Pre-K English Teacher Professional Development Programme, and 54.2\% of the participants believed that English was merely a class in a specific schedule, as it is shown in figure 1.

Nonetheless, preschool educators were asked how they considered the teaching of English to the children in their classes after being part of the Pre-K English Teacher Professional Development Programme, and 95.8\% of the participants believed that English was seen as a whole and as an integral element of preschool education beyond a simple class moment, as it is seen in figure 2 . 
Q15: Before particpating in Pre-K English Programme, your conception about English based on your teaching practices was

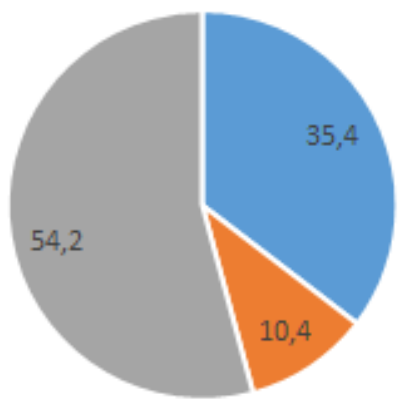

- Option 1 - Option 2 = Option 3

Figure 1. Questionnaire: Impacto del Programa Desarrollo Profesional Docente Pre K-English en las Prácticas de Aula en Educación Inicial de las Maestras Participantes.

Note:

Option 1: A regular English class within a specific schedule.

Option 2: A transversal process where English is part of the academic day.

Option 3: English is not in the school's curriculum.
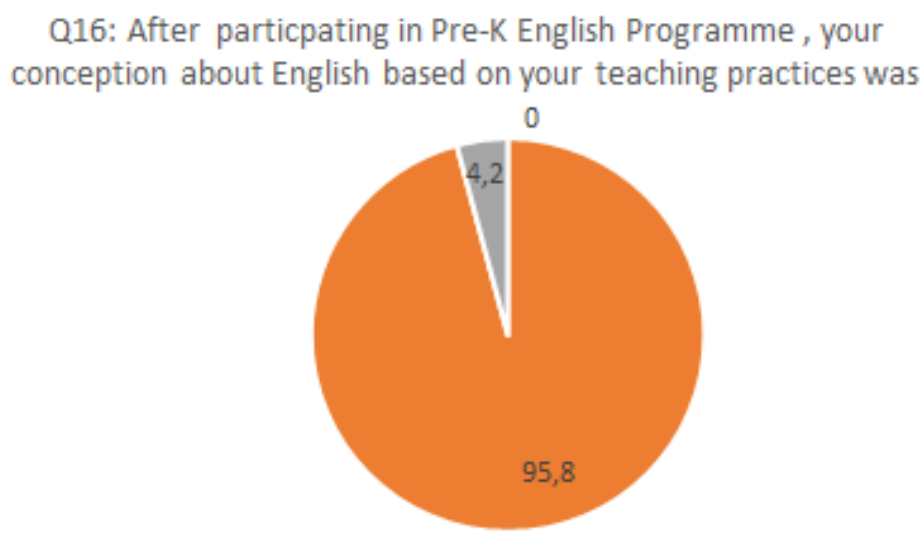

- Option 1 - Option 2 - Option 3

Figure 2. Questionnaire: Impacto del Programa Desarrollo Profesional Docente Pre $K$-English en las Prácticas de Aula en Educación Inicial de las Maestras Participantes.

Note:

Option 1: A regular English class within a specific schedule.

Option 2: A transversal process where English is part of the academic day.

Option 3: English is not in the school's curriculum. 
These results allow this research study to state that all preschool educators who participated in a Professional Development programme agreed on the fact that English should be seen as a whole and an integral element of preschool education that enables many children's benefits.

\section{English Learning Processes Transformations}

Learning is a constant experience where educators should become the most motivated and determined learners, so that their processes can lead to a full understanding of the pupil's progression and motivation. Preschool educators in this program developed a strong sense of understanding of the real transformations in front of learning. There were many challenging moments where preschool educators needed to change their attitudes towards the language and their knowledge of it, which encouraged them to view English teaching as part of a more comprehensive language competence practice. In chorus, their own needs and societal demands have made them believe in the importance of transforming the classroom into a learning space where mistakes, questions, and every single interaction give rise to learning for all participants: preschool educators and students.

In this regard, Kumaravadivelu (2002) proposed some macro-strategies connected to preschool educators' English learning processes transformations. A first sight, the macro-strategy of "Promoting learner autonomy" considers how to provide language learners with the essential means to become autonomous, providing them with opportunities to self-monitor, self-regulate, and self-direct their learning. In this regard, one of the preschool participants affirmed:

Being part of the Pre-K English Programme has made me feel lucky since, through this program, I have expanded my knowledge of English use. Besides, I managed to acquire learning tools that have allowed preschool educators to transmit new knowledge to boys and girls. (JournalTraveling Notebook 2017 -PE\#1)

The macro-strategy of "Fostering language awareness" bears upon how to make learners conscious of the formal and functional qualities of language formative processes. On top of that, a preschool teacher participant stated:

Participating in a professional programme like Pre-K English is an excellent opportunity to grow personally and professionally. The topics and methodology allow me to strengthen and expand my knowledge; I have 
also acquired new strategies to teach English to children in a didactic way, enabling more meaningful and enriching learning. (Journal- Traveling Notebook 2017- PE\#2)

Hence, a macro-strategy consists of providing enough rich textual resources to activate intuitive heuristics, allowing learners to internalize the grammatical rules and their communicative use. It is equally crucial to reflect upon how language usage and language use is constructed by linguistic, extra-linguistic, situational, and extra-situational settings: this macro-strategy is called: Contextualizing Linguistic Input. The holistic integration of the four necessary language skills listening, speaking, writing, and reading has been named integrated language skills. On this subject, a preschool teacher participant expressed:

The changes compared to learning English have been significant since belonging to the Pre-K English Programme improves the order of ideas that are more effective for the teacher-student relationship, and it helps to improve speaking, listening, reading, and writing activities. (JournalTravelling Notebook, 2017- PE\#3)

Alongside, ensuring social relevance is a macro-strategy that considers educators' need to become thoughtful when teaching processes deal with social, cultural, political, and economic issues in second language acquisition. As a final point, raising cultural consciousness bears the requirement to treat learners as cultural informants to engage them in-class participation. Related to this, a preschool teacher participant set "Preschool educators should teach a language with gladness, not as another subject that must be taught to fulfil the curriculum but transform teaching from the cultural and social perspectives that a language brings" (Journal- Travelling Notebook, 2017- PE\#5).

\section{Development and improvement of the communicative}

\section{competence.}

One of the primary purposes of this program was to help in the improvement of preschool educators' communicative competence. Throughout engagement in a meaningful language learning process, using different strategies, utilizing language and the expressive arts, participants (learners and preschool educators) showed that they could improve in the following communicative components: sociocultural, discourse, and grammatical competence. This finding will be explained in a logical order. 
Discourse and Grammatical Competence Improvement. Along the process, Pre-K English participants were administered two tests to measure their linguistic level. When comparing both tests' results, there is an evident improvement in discourse competence. Preschool Educators lacked an accurate use of language structures in the diagnostic test, which affected their discourse, but after Pre-K classes, preschool educators greatly improved their performance. Moreover, in the diagnostic test, the participants' use of punctuation in the writing section was often incorrect, with consequences for their ability to communicate, but their final products showed significant improvement.

Preschool Educators' tests also showed improvement in the grammatical competence of participants. According to Savignon (2001), syntax and lexicon are components of that competence. Comparing the diagnostic test to the final one. Figure 3 shows how preschool educators improved their discourse and grammatical competence.

\section{Diagnostic and Final Test Comparison}

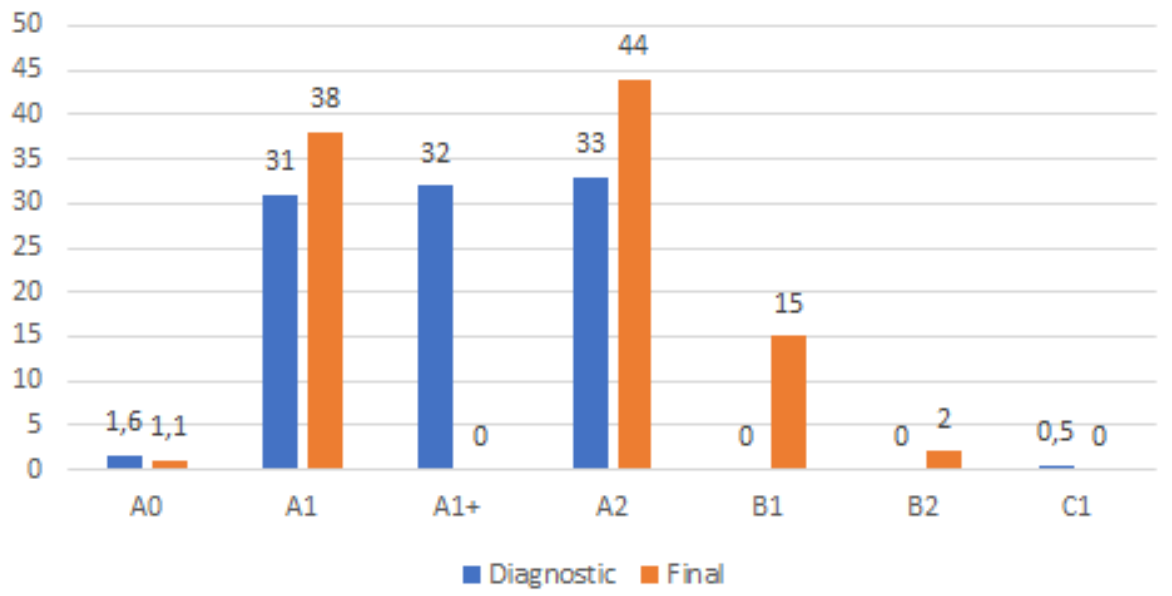

Figure 3. Diagnostic and Final Test Comparison

Note. The tests were designed based on the MCER descriptors.

Sociocultural Competence Improvement. An improvement in the socio-cultural competence was evident after the language learning process as preschool educators' developed awareness of different views and perspectives of the target language. Sauvignon (2001) describes the socio-cultural competence as a component that "requires an understanding of the social context in which language is used: the roles of the participants, the information they 
share, and the function of the interaction" (p. 18). For example, using the correct methods, approaches, strategies and methodologies in language teaching and learning processes develop a socio-cultural competence regarding what learners are able and need to learn.

The following excerpts, from the Journal- Traveling Notebook, highlight some of the participants' opinions regarding the role of the language within their teaching and social scenarios.

"It is the opportunity to grow as a teacher, improving training processes, but at the same time, it is the space to learn from peers and their practices in the classroom". (Journal- Traveling Notebook 2017- PE\#6)

"Pre-K English is a complete professional development program that allows progress and development of processes, respecting the rhythms and values the achievements". (Journal- Traveling Notebook 2017- PE\#7)

Participating in a programme that seeks to strengthen the use of English in preschool is to open a wide range of pedagogical and creative possibilities for English teaching. Re-signifying the educator's role from a student position, that is, "learn to teach," but it is also a "let us learn together. (Journal- Traveling Notebook 2017- PE\#8)

The Pre- $K$ English Professional Development Programme had the desire to qualify the pre-school educators of Medellin starting from the base to sow the seed of knowledge in public institutions, starting from love and promoting activities that contribute to filling our knowledge and transmitting them. (Journal- Traveling Notebook 2017- PE\#9)

\section{Confidence Preschool Educators Development}

One of the contributions from the Pre-K English Programme was a development in preschool educators' confidence. In reflections, Preschool Educators expressed feelings that showed self-efficacy, defined as "judgments of their ability to perform a task" (Pintrich, 2002, p. 222). As seen in the following excerpts, from Journal- Traveling Notebook 2017 designed during the program, named as Cuaderno Viajero, ${ }^{1}$ Preschool educators understood the need to see this process as a personal one, where learning the language was not the difficult aspect; changing the process was seen and assumed in

1 This was a journal created to write what Pre-K English 2017 meant in the people who made it a reality at the Luis Amigó Catholic University classrooms and in those of the Educational Institutions of the city of Medellín. 
order to overcome the obstacle of fearing making mistakes in front of the class, dedication, disposition and openness.

Participating in a Programme that seeks to strengthen the use of English in preschool is to open a wide range of pedagogical and creative possibilities for the teaching of English. Re-signifying the role of the educator from a student position, that is, "learn to teach", but it is also a "let's learn together. (Journal- Traveling Notebook 2017- PE\#10)

Being part of Pre-K has made me feel very fortunate, since, through this program, I have been able to expand my knowledge of the use of English. I have also managed to acquire learning tools that have allowed me to transmit new knowledge to boys and girls. (Journal- Traveling Notebook 2017- PE\#11)

\title{
Communicative Competence in child development
}

\author{
"the teacher needs to acknowledge what kids know \\ and to see this as a different possibility"
}

(Focus group)

During this investigation, researchers and participants realized that to foster a real communicative competence in both languages, Spanish and English, the preschool educators' position is a crucial element; it is a component that takes them to understand deeply the processes of learning and teaching that should be embraced in preschool classrooms. Preschool processes should not be oversimplified in the assumption that pupils are not ready to confront new perspectives and deep concepts and participate in the act of negotiation. The preschool pupil concept and his/her human development should be strengthened, as well as the notion of communication and learning languages in the preschool scenario. There must be a clear connection within the teaching sequence between the aims, standards, and methodology to be used, as well as constant reasoning about the teacher's praxis that responds to communication as an exercise to stand position and give children a voice beyond the simple fulfilment of legal requirements within the national or local curriculum.

To exemplify the aforementioned, figure 4 shows that $45.8 \%$ of the participants concluded that the fact of participating in a program like Pre-K English, allowed them to design teaching scenarios that took preschool students to improve their communicative competences development. Besides, as it is seen 
in figure $5,75 \%$ of the interviewed expressed that their participation in the program took them to consider other aspects such as children characteristics, abilities and interests while teaching a language, like English, and this fact permits children to notice new standpoints in different cultures.

\section{Q7: After participating in Pre-K English \\ Programme, students showed the development of the communicative competence}

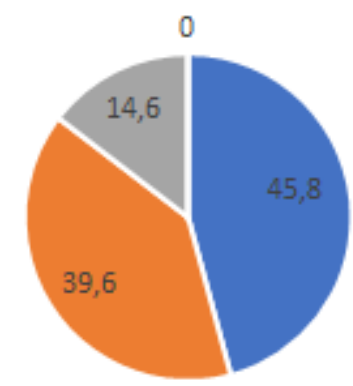

- Always -Almost always "Sometimes "Nevel

Figure 4. Questionnaire: Impacto del Programa Desarrollo Profesional Docente Pre K-English en las Prácticas de Aula en Educación Inicial de las Maestras Participantes.

\section{Q8: After participating in Pre-K English Programme, I focus my planning on}

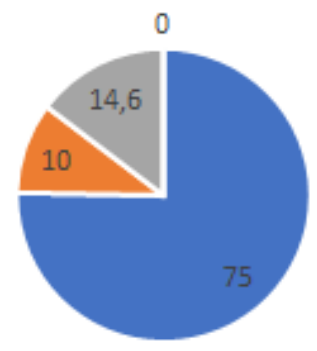

\footnotetext{
- Children's characteristics | Teaching Objectives

- Teaching approaches | All of the above
}

Figure 5. Questionnaire: Impacto del Programa Desarrollo Profesional Docente Pre K-English en las Prácticas de Aula en Educación Inicial de las Maestras Participantes. 


\section{Conclusions}

It is necessary to consider the pedagogical and didactic options that preschool educators will compose to be well equipped before they teach the language regarding English teaching and learning processes. These options instil them with confidence to take risks and adventure within the target language, academic life, and professional development. In this sense, teaching English processes should not be a burden for learners and preschool educators, but rather a process that affects both in a positive way. Language educators need to take chances and implement this systematic process in the language classroom because learners greatly benefit from it.

Drawing on the results obtained in this study, it is asserted that preschool educators' academic performance is the process and result in which pedagogical and didactic options-related factors, context adjustment actions, and adaptation are involved in a dialogical and reciprocal relation. Therefore, preschool educators and learners' academic performance becomes a multidimensional concept in which principles, attitudes, and knowledge are connected in a positive construction where preschool educators develop a self-perception of their limitations, competencies, and accomplishments. Consistently, preschool educators must observe how learners' backgrounds enter the class to offer them opportunities to express different learning situations within the language classroom. In this sense, preschool educators should aim at transforming classes in time and spaces for students to express who they are and how they live.

From the Pre-K Professional Development Programme perspective and equity, it is believed that any difference should represent an opportunity for the improvement of English teaching processes. Based on this perspective, it is thought that when preschool educators are given opportunities to work collaboratively in everyday academic jobs, they acquire autonomous values that produce improved academic performance. According to Burke and Short (1991), collaboration is considered by how a group of members thinks and works together. She also mentions that "as socio-affective human beings, we actively seek relations with others. Our emotional, intellectual and physical wellbeing is invested in others because it is as social beings that our worlds become multidimensional" (p. 14). The development of pedagogic and didactic options contributes to encouraging interactions as any educator learns about themselves, the others, and the education in general. 


\section{References}

Amaya de Ochoa, Gabriela. (1997) La escuela, el maestro y su formación. En: la formación de los educadores en Colombia. Compilación. Misión Ciencia, Educación y Desarrollo. Instituto para la investigación Educativa y el desarrollo pedagógico IDEP. Santa Fé de Bogotá, 1997. P. 54. M

Burke, C., \& Short, K. (1991). Creating curriculum: Teachers and students as a community of learners. Portsmouth, NH: Heinemann.

Canale, M. (1983). From communicative competence to communicative language pedagogy. In Richards, J. C., \& Schmidt, R. W. (Eds.), Language and Communication, 2-27. London: Longman.

Canale, M., \& Swain, M. (1980). Theoretical bases of communicative approaches to second language teaching and testing. Applied Linguistics, 1, 1-47.

Chomsky, N. (1965). Aspects of the Theory of Syntax. Cambridge, Massachusetts: The M.I.T. Press.

Creswell, John W. (2014). Research Design. Qualitative, Quantitative and Mixed Methods Approaches. Fourth ed. Lincoln: Sage Publications.

Fundación Nutresa, Secretaría de Educación de Medellin \& Universidad Católica Luis Amigó (2014). Acuerdo de voluntades [Heads of Agreement]. [Working paper]. Medellin: January 23.

Fusch, P. I., \& Ness, L. R. (2015). Are We There Yet? Data Saturation in Qualitative Research. The Qualitative Report, 20(9), 1408-1416. Retrieved from https:// nsuworks.nova.edu/tqr/vol20/iss9/3

House, S. (1997). An introduction to teaching English to children. London: Richmond Publishing.

Galeano, M. Eumelia (2004). Diseño de Proyectos en la Investigación Cualitativa. Universidad Eafit Medellín.

Kishore, C.S. (2000, January). A Noble Profession. Retrieved January 28, 2008, from http://www.cskishore.com/teaching.htm.

Krashen, S. D. (1981). Second language acquisition and second language learning (Vol. 2). Oxford: Pergamon Press.

Kumaravadivelu, B. (2002). Beyond methods: Macrostrategies for language teaching. Yale University Press.

Kumaravadivelu, B. (2009). Language Teaching Methods. In Understanding Language Teaching. From Method to Postmethod, (pp 83-157). New York: Routledge. 
Loaiza-Zuluaga, Y., Sánchez-Girado, D., Arias-Arteaga, G. y Palacio-Bernal, J. (2019). Las prácticas pedagógicas en el campo de la educación: su confluencia en investigaciones de posgrado de la UCM. Revista de Investigaciones UCM, 19(33), 50-64.

Maturana-Patarroyo, L. M. \& Uribe-Hoyos, C. M. (2018). Enhancing Pre-K Teachers' Personal and Professional Transformation by Articulating Two University Extension Approaches: A Reflection. Íkala, Revista de Lenguaje y Cultura, 23(1), 161-176. DOI: 10.17533/udea. ikala. v23n01a11

Pintrich, P. (2002). The role of metacognitive knowledge in learning, teaching, and assessing. Theory into Practice: Revising Bloom's Taxonomy, 41(4), 219-225.

Roberts, T. A. (Ed.). (2009). No limits to literacy for preschool English learners. Corwin Press.

Savignon, S. J. (2001). Communicative language teaching for the twenty-first century. In M. Celce-Murcia (Ed.), Teaching English as a second or foreign language, (pp. 13-28). Boston, MA: Heinle and Heinle.

Scott, W. A., \& Ytreberg, L. H. (1990). Teaching English to children. London: Longman. Universidad Católica Luis Amigó (2017). Sistematización del programa. Programa de Desarrollo Profesional Docente: Pre-K English. Medellín: Universidad Católica Luis Amigó.

Wallace, Michel J. (1991). Training Foreign Language Teachers: A Reflective Approach. Cambridge Teacher Training and Development. Cambridge University Press. 1991.

Widdowson, H. G. (1983). Learning Purpose and Language Use. Oxford: Oxford University Press. 